\title{
South Africa Micro Entrepreneurs: Mobile ICT Adoption
}

\author{
Eunice Steyn, Riana Steyn, and Carina De Villiers \\ Informatics, University of Pretoria, Pretoria, South Africa \\ eunicesteyn@gmail.com riana.steyn@up.ac.za \\ carina.devilliers@up.ac.za
}

\begin{abstract}
The objective of this paper was to determine the perceived barriers and motivators of mobile ICT adoption by South African micro entrepreneurs. Current research shows that mobile ICT can help ensure the success of micro enterprises. However, there are barriers and motivating factors, which influence the mobile ICT adoption rate of micro enterprises and they seem to differ between countries. Semi-structured interviews with a number of South African micro entrepreneurs were used in this study to determine the barriers and motivators relevant in a South African context. The results from this study show that each individual entrepreneur has their own subset of factors, unique to their situation and environment, which influences their ICT adoption rate. Attempts to increase the mobile ICT adoption rate amongst South African entrepreneurs therefore needs to consider the unique set of mobile ICT adoption barriers and motivators that each entrepreneur faces.
\end{abstract}

Keywords: Entrepreneurs, Micro-enterprises, ICT, Mobile, adoption, Motivators, Barriers

\section{Introduction}

South Africa faces a growing unemployment crisis and micro enterprises (MEs) are a vital tool through which the country can address pressing challenges such as job creation and economic growth (Herrington, Kew, \& Kew, 2009). According to the National Small Business Amendment Act of South Africa (D.O.T.I., 1996) a business must not employ more than five people or have an annual turnover of more than R200 000 to be classified as a micro enterprise. This paper will focus only on entrepreneurs with businesses that align to this classification.

Herrington et al. (2009) reports that in 2009 South Africa recorded only 7.2\% entrepreneurial activity, in comparison to the $18.8 \%$ Global Entrepreneurship Monitor survey average. They have found that many entrepreneurial businesses in South Africa never progress beyond the start-up

Material published as part of this publication, either on-line or in print, is copyrighted by the Informing Science Institute. Permission to make digital or paper copy of part or all of these works for personal or classroom use is granted without fee provided that the copies are not made or distributed for profit or commercial advantage AND that copies 1) bear this notice in full and 2) give the full citation on the first page. It is permissible to abstract these works so long as credit is given. To copy in all other cases or to republish or to post on a server or to redistribute to lists requires specific permission and payment of a fee. Contact Publisher@,InformingScience.org to request redistribution permission. phase, implying that MEs face many challenges.

One of the ways in which MEs can ensure their success is by making use of Information Communication Technology (ICT), as it is a main contributor to entrepreneurial success and holds many benefits for MEs (Kenny, 2002,;

Kotelnikov, 2007). Mutula and Van Brakel (2007) for instance recognize ICT as a valuable tool for socio- 
economic development. However, despite the value that ICT holds for ME entrepreneurs these technologies are either underutilized or not used at all (Herrington et al., 2009; Ilavarasan \& Levy, 2012).

As the usage of ICT at the lower end of the ME spectrum is dominated by mobile telephone usage, this would be the most effective technology to use for MEs, mainly due to its portability (Svanaes, Alsos, \& Dahl, 2010). Donner and Escobari (2010) found voice calls to be the highest rated use of mobile technology and in a study conducted across 13 African countries, it was determined that $76 \%$ of small businesses use mobile phones to communicate with their customers, which was much higher than fixed telephone lines or fax machines (Esselaar, Stork, Ndiwalana, \& Deen-Swarray, 2006). In that same study $95 \%$ of SMEs rated mobile phone as the most desired ICT to be used in their business. Kabanda (2001) found that SMEs prefer using their mobile devices as this ensure and connects them to the "wider, changing social world". As she rightfully states: "By acquiring this resource (the mobile device) SMEs had the power to change their current practices" (Kabanda, 2001, p. 11). Mobile phones should be seen as "a primary candidate to facilitate participation as part of an e-collaboration effort" (Twinomurinzi, Phahlamohlaka, \& Byrne, 2012, p. 210).

When reviewing the literature on micro entrepreneurs in South Africa, very little could be found on the barriers of mobile ICT adoption.

This paper seeks to identify and address these barriers, which exist in the micro enterprise environment, by making use of the interpretivist paradigm with qualitative data analysis. The perceptions that South African micro entrepreneurs have of mobile ICT, how these perceptions were formed and what other barriers and motivators these entrepreneurs feel influence their adoption of mobile ICT will be explored. This paper forms part of an Honors student's work in conjunctions with one of the researches' $\mathrm{PhD}$ studies.

The research questions addressed in this paper are:

- What is currently preventing South African entrepreneurs from using mobile ICT in their businesses?

- Why or for what purposes ME entrepreneurs are currently using mobile technology?

- What are the current perceptions that these entrepreneurs have of mobile information technology

\section{Literature Review}

\section{Current Trends and Levels of ICT Use}

Molony (2009) establishes that ICT is a crucial tool with which to build networks and expand an entrepreneurial venture into new markets. His research reveals that Tanzanian entrepreneurs mainly use mobile phones to retain rather than attract clients, by enabling them to strengthen relationships with their existing clients. Donner (2007) has also found that the growth in ICT adoption in developing countries is phenomenal. This is in contrast with Herrington et al. (2009) who asserts that the low rate of ICT adoption could lead to significant growth in the digital divide. Similarly Kirkwood and Price (Kirkwood \& Price, 2005) note that even though ICT can be seen as a tool to empower and enhance the people within South Africa, this "advantage" could in fact lead to an even greater "digital divide". Chibelushi (2008) found that ICT orientated MEs, whom one would assume understand the value of ICT, show lower adoption rates than expected.

Mobile technology, in particular mobile phones, appears to be the most popular ICT used by MEs. Steyn (2011) notes that South African MEs prefer to use mobile phones to communicate 
with their suppliers as well as customers; and found that more than $70 \%$ of the entrepreneurs in could use their mobile phones to connect to the internet. However, only a small portion of the mobile's capabilities are currently being used ( Chew et al., 2010; Donner, 2007; Ilavarasan \& Levy, 2012). Molony (2009) for instance finds that successful Tanzanian MEs only use their mobile devices to call suppliers or to text clients with delivery information. The main reasons for the popularity of mobile phones are found to be its accessibility, affordability and the fact that it requires very little training (Esselaar et al., 2008). One should note that the perception that mobile phones require little or no training, might be the cause for the underutilisation of mobile phone capabilities, as MEs are not trained to exploit its full capabilities.

Esselaar et al. (2008) find that mobile technology provides an easy and flexible means to communicate with suppliers and customers. However, they also find that the promotion of the mobile phone, as the main ICT for MEs, is limiting, since the mobile phone cannot grow and develop as the SME is developing (it cannot be modified or adjusted to suit the changing needs of the ME). Currently, the mobile phone cannot be used to produce income statements, formal letters or brochures. All of which could be produced using any of the recently developed tablet PCs.

\section{The Impact of ICT on Entrepreneurial Ventures}

ICT is recognised for its potential to contribute to the improvement of performance and competitiveness of business ventures (Morgan et al., 2006) and it is also perceived by many to be a vital tool for businesses (Herrington et al., 2009). There is an increased need for small businesses to leverage the use of ICT to enhance their business as part of the country's socio-economic development, however, the growing skill shortage regarding how to use ICT is also recognised (Mutula \& Van Brakel, 2007; Uddin, 2005). Certain studies have found that information technology variables are insignificant in the success of a start-up (Reid \& Smith, 2000). Kotelnikov (2007) and Donner (2004) also caution that not all MEs face the same challenges and therefore, that they do not all need complex or extensive IT solutions, ICT should rather be manipulated to suit each individual's need. This is very different to most findings (Barba-Sánchez, Martinez-Ruiz, \& Jimenez-Zarco, 2007; Bourgouin, 2002; Donner \& Escobari, 2010; Matthews, 2007; Tan, Macaulay, \& Scheurer, 2006) where authors encourage the use of ICT by MEs, without noting their different and individual needs.

Additionally, Matthews (2007) cautions against accrediting growth in an ME directly to the use of ICT, as there could be other factors, which contribute to the improvement and success of an ME along with ICT. He mentions that it is likely that ICT adoption will only affect growth when accompanied by other changes in the organisation. He also states that the perception of benefits achieved is often greater than when it is measured. Barba-Sánchez et al. (2007) also recommend that other areas of adjustment like organisational structure should be evaluated when determining the strategic value of ICT, and not only the features of newly adopted technologies.

\section{Factors Affecting the Adoption and Use of ICT}

Morgan et al. (2006) report that there are various difficulties, which prevent MEs from accessing the benefits that ICT offers. Thompson, Williams, Thomas and Packham (2010) acknowledge that even though ICT can be seen as a huge benefit to SMEs, it also brings about a threat for these SMEs and entrepreneurs as they have mostly limited resources available to optimally use and benefit from these technologies. This threat can be seen as a barrier which SMEs and entrepreneurs will have to overcome in order for them to introduce ICT or even ensure a sustainable business which incorporates ICT. However, no two authors identify the exact same list of adoption barriers. To depict this, Table 1 shows the factors that are frequently mentioned by various authors. 
Table 1: Factors Influencing ICT Adoption

\begin{tabular}{|c|c|}
\hline Reason to adopt or not & Source \\
\hline Lack of resources & $\begin{array}{l}\text { Mutula and van Brakel (2007); Kahn et al. (2012); } \\
\text { Miller and Garnsey (2000); Thomas et al. (2004); } \\
\text { Reimenschneider et al. (2003); Nguyen (2009); } \\
\text { Chatzoglou and Vraimaki (2010); Kabanda (2001) }\end{array}$ \\
\hline $\begin{array}{l}\text { Difficult to retain current workforce; lack of skills } \\
\text { and human capital development }\end{array}$ & $\begin{array}{l}\text { Mutula and van Brakel (2007); Kapurubandara and } \\
\text { Lawson (2007); Kahn et al. (2012); Miller and } \\
\text { Garnsey (2000); Nguyen (2009); Esselaar, Stork, } \\
\text { Ndiwalana and Deen-Swarray (2006); Ladzani and } \\
\text { van Vuuren (2002) }\end{array}$ \\
\hline Effective Leadership, ownership and management & $\begin{array}{l}\text { Spencer et al. (2012); Uddin (2005); Kahn et al. } \\
\text { (2012); Miller and Garnsey (2000) }\end{array}$ \\
\hline Access to information, strategy & Kahn et al. (2012) \\
\hline Political and social barriers & Kapurubandara and Lawson (2007) \\
\hline $\begin{array}{l}\text { Security concerns; mistrust regarding ICT and ICT } \\
\text { service providers; Lack of trust }\end{array}$ & $\begin{array}{l}\text { Gatautis and Vitkauskaite (2009); Kapurubandara } \\
\text { and Lawson (2007); AlAwadhi and Morris (2008); } \\
\text { Wamuyu and Maharaj (2011); Cohen et al. (2013) }\end{array}$ \\
\hline $\begin{array}{l}\text { Lack of infrastructure, technical challenges (risk of } \\
\text { the product malfunctioning) }\end{array}$ & $\begin{array}{l}\text { Kahn et al. (2012); Kapurubandara and Lawson } \\
\text { (2007); Ramani et al. (2012); Suri (2011); Nguyen } \\
\text { (2009); Esselaar et al. (2006); Wamuyu and } \\
\text { Maharaj (2011) }\end{array}$ \\
\hline Legal framework; Legal aspects & $\begin{array}{l}\text { Kahn et al. (2012); Kapurubandara and Lawson } \\
\text { (2007); AlAwadhi and Morris (2008) }\end{array}$ \\
\hline Cultural barriers or constraints & $\begin{array}{l}\text { Kapurubandara and Lawson (2007); Kahn et al. } \\
\text { (2012) }\end{array}$ \\
\hline $\begin{array}{l}\text { Lack of a one-shop facility and access to reliable } \\
\text { experts; difficulty of keeping systems serviced and } \\
\text { upgraded }\end{array}$ & $\begin{array}{l}\text { Kapurubandara and Lawson (2007); Thomas et al. } \\
\text { (2004); Ndubisi and Kahraman (2005); Ladzani } \\
\text { and van Vuuren (2002) }\end{array}$ \\
\hline Financial constraints, high costs & $\begin{array}{l}\text { Kahn et al. (2012); Ramani et al. (2012), Thomas et } \\
\text { al. (2004); Nguyen (2009), Esselaar et al. (2006), } \\
\text { Donner and Escobari (2010), Ndubisi and } \\
\text { Kahraman (2005); Ladzani and van Vuuren (2002); } \\
\text { Wamuyu and Maharaj (2011) }\end{array}$ \\
\hline $\begin{array}{l}\text { Lack of knowledge, unfamiliar, thus leading to } \\
\text { perception that ICT is to complicated; lack in } \\
\text { confidence }\end{array}$ & $\begin{array}{l}\text { Ramani et al. (2012); Esselaar et al.(2006); Ndubisi } \\
\text { and Kahraman (2005); AlAwadhi and Morris } \\
(2008) \text {; Kabanda (2001) }\end{array}$ \\
\hline $\begin{array}{l}\text { Access to mobilasation of organisational resources } \\
\text { (such as reputation and brand equity) }\end{array}$ & Miller and Garnsey $(2000)$ \\
\hline No need for ICT & Esselaar et al. (2006) \\
\hline Limited availability & Donner and Escobari (2010); Oye et al. (2012) \\
\hline $\begin{array}{l}\text { Performance risk (Increase in productivity due to } \\
\text { ICT, increase in job performance, useful for my } \\
\text { work) }\end{array}$ & Wamuyu and Maharaj (2011) \\
\hline
\end{tabular}

Tan et al. (2006) interestingly find that even if some barriers like high costs and lack of government support are removed MEs still tend to be reluctant to adopt ICT. This might be an indication that there are other, yet unknown factors that play a role in adoption. 


\section{Research Methodology}

Extensive research on the relationship between MEs and their use of ICT was conducted in previous studies. It is also observable that very little research was done to identify the factors, which motivate and prevent South African MEs from using mobile ICT.

This paper will use the Interpretivist paradigm due to the social nature of MEs. Myers (2009) as well as Klein and Myers (1999) note that human sense-making is complex and that one cannot have pre-defined variables when conducting the research. Similarly, Saunders et al. (2003) realises that business situations are unique and complex and that there is a huge focus on the social aspects within which these businesses operate. Due to the fact that the MEs are mostly owned by one owner, who is typically also the decision maker, conducting interpretive research should provide an insight into the perceptions that South African entrepreneurs have of ICT, how these perceptions are formed and how they influence ICT adoption specifically focusing on mobile devices. Semi-structured interviews have been conducted to collect qualitative information. The interview consists of a series of open and closed questions, aimed at obtaining standard demographic data and moving on to the ICT related perceptions and opinions. Each interview contains the same basic questions but allows for expansion or additional questions as each interview progresses.

The target population for this research consists of entrepreneurs in South Africa's urban areas. The non-probability sampling techniques, purposive and convenience sampling is used to select the sample of ten entrepreneurs from different locations in Pretoria. Based on the criteria of the National Small Business Amendment Act of South Africa (D.O.T.I, 1996) the interviewed entrepreneurs can all be classified as micro entrepreneurs.

Due to the nature of the demographic data, this small portion of the data was analysed by using a quantitative data analysis approach. The rest of the data gathered is qualitatively analysed to ensure that the perceptions, opinions and open-ended questions provide the correct information.

\section{Data Analysis}

The data analysis will now be discussed based on various themes, which emerged from both the literature and the interview questions.

\section{Adoption Levels of Mobile ICT}

Table 2 outlines the difference between the various levels of adoption based on those specified by Hermana, Sugiharto, and Margianti (n.d.).

Table 2: Classification of mobile ICT adoption level (Hermana, Sugiharto, and Margianti, (n.d.)

\begin{tabular}{|l|l|}
\hline Level of mobile ICT adoption & Description \\
\hline Non adopter & No mobile information technology is used. \\
\hline Low adopter & $\begin{array}{l}\text { One form of mobile ICT is used for basic communication pur- } \\
\text { poses. Typically, a mobile phone is used for communicating } \\
\text { with buyers and suppliers. }\end{array}$ \\
\hline Medium adopter & $\begin{array}{l}\text { One or more forms of mobile ICT used for basic communica- } \\
\text { tion purposes as well as some other functions. Typically, a } \\
\text { mobile phone and another form of mobile ICT like a laptop. } \\
\text { Additional functions are typically mobile banking. }\end{array}$ \\
\hline High adopter & Multiple mobile ICT forms are used extensively. \\
\hline
\end{tabular}


Based on the levels in Table 2, it has been found that the interviewed entrepreneurs could be classified as shown in Table 3.

Table 3: Level of mobile ICT adoption

\begin{tabular}{|l|l|}
\hline Mobile ICT adoption level & Number of entrepreneurs \\
\hline Non adopter & 0 \\
\hline Low adopter & $3(\mathrm{~W}) 2(\mathrm{M})^{*}$ \\
\hline Medium adopter & $1(\mathrm{~W}) 2(\mathrm{M})$ \\
\hline High adopter & $1(\mathrm{~W}) 1(\mathrm{M})$ \\
\hline
\end{tabular}

$* \mathrm{~W}=$ women $\quad \mathrm{M}=$ men

Most of the entrepreneurs are low adopters of mobile technology. Mobile phones are the most popular form of ICT used by all interviewees and only half of them make use of the internet capabilities of their phones. This is in contrast with the findings of Steyn (2011). However, what is clear is that not all interviewees are connected to the internet, which restricts their ability to use a phone for business gain.

\section{Gender of Interviewees}

Chew et al. (2010) have found that gender norms play a big role in whether an entrepreneur will adopt mobile technology. Chew et al. (2010) find that the more positive a female entrepreneur feels about her status and power because of her business venture, the more motivated she will be to make use of ICT for business purposes. The five men are slightly higher adopters of mobile ICT than the five women we have interviewed, reflecting the findings of Chew et al. (2010) to some extent. Certain female entrepreneurs seem to rely heavily on what their husbands think and decide concerning ICT. One interviewee relied on her husband for training and another has turned down the chance to use additional mobile ICT because her husband thinks she does not need it.

\section{Primary space of Business (Location)}

Two of the entrepreneurs conduct their business from the grounds surrounding the Union Buildings in central Pretoria, four hawk their wares on the corner of Solomon and Francina streets in the east of Pretoria and three entrepreneurs are located in various parts of Mountain View, north of Pretoria.

\section{Type of Organisation}

Kotelnikov (2007) and Donner (2004) found that not all MEs have to use mobile ICT as extensively or have the same ICT needs as others. The type of organisation would therefore contribute to the level of mobile ICT adoption. (See Table 4)

Only three of the interviewed entrepreneurs have service-based businesses and the rest sell goods. Three have a formal business property and seven are classified as street vendors.

Table 4: Type of organisation versus level of adoption

\begin{tabular}{|l|l|}
\hline Level of adoption & Type of organisation \\
\hline Low adoption & Goods: 5 \\
\hline Medium adoption & Services: 2 Goods: 1 \\
\hline High adoption & Services: 1 Goods: 1 \\
\hline
\end{tabular}


Interestingly the service-based businesses have a higher adoption rate than those selling goods. There is also no real difference between street vendors and those with formal businesses in terms of ICT adoption. Two of the street vendors have mentioned that they would make use of more technology, if they had a safe environment with access to electricity from which to conduct their business.

\section{Size of your Business in Terms of Employees and Annual Turnover (less than R 200 000)}

This question tries to determine whether organisational size influences the level of ICT adoption (MacGregor, 2004). MacGregor (2004) has found that smaller firms lack the skills and capital to be high level adopters.

The two high adopting MEs interviewed employ only the owner, while the majority of low adopters employ three to five people. This contrasts with MacGregor's (2004) findings that the larger the organisation, the higher its adoption. One must note, however, that his research has focused on large organisations. What could be true for these findings is that the two high adopters have a bigger workload, due to working alone, while realising the need to communicate with their suppliers and certain customers resulting in the increased use of Mobile ICT to work smarter and more efficient.

\section{Highest Level of Education}

A person's level of education plays a major role in the adoption of ICT in their businesses (Chew et al., 2010; Chibelushi, 2008). Table 5 shows the level of education of each entrepreneur alongside their level of mobile ICT adoption.

Table 5: Education versus mobile ICT adoption level

\begin{tabular}{|l|l|l|}
\hline Highest level of education & Mobile ICT adoption level & Number of entrepreneurs \\
\hline Grade 10 & Low adopter & 1 \\
\hline Grade 12 & $\begin{array}{l}\text { Low adopter } \\
\text { Medium adopter }\end{array}$ & 4 \\
\hline $\begin{array}{l}\text { Qualified fitter and turner } \\
\text { diploma }\end{array}$ & High Adopter & 1 \\
\hline Degree & $\begin{array}{l}\text { Medium adopter } \\
\text { High adopter }\end{array}$ & 1 \\
\hline Honours degree & Medium adopter & 1 \\
\hline
\end{tabular}

Table 5 shows that the higher the entrepreneur's level of education, the more likely they are to have a higher level of mobile ICT adoption. This supports the findings by Chibelushi (2008) and Chew et al. (2010).

\section{Primary Use of Mobile ICT device}

Chew et al. (2010) state that MEs only use a portion of a mobile phone's capabilities. Various findings support this statement, with mobile phone use being limited to contacting suppliers and clients and sometimes finding information via the internet (Chew et al., 2010; Donner \& Escobari, 2010; Esselaar et al., 2008; Tenhunen, 2008). Molony (2009) also finds that MEs use mobile phones to retain rather than attract clients. 
The micro entrepreneurs in this study responded as shown in Table 6:

Table 6: Uses of mobile ICT

\begin{tabular}{|l|l|}
\hline Use of mobile ICT & Number of entrepreneurs \\
\hline Communication with clients & 7 \\
\hline Mobile banking & 1 \\
\hline Communication with suppliers & 7 \\
\hline Communication with employees & 2 \\
\hline Coordinating deliveries and orders & 4 \\
\hline Mobile advertising & 1 \\
\hline
\end{tabular}

The fact that some entrepreneurs make use of mobile banking and mobile advertising in addition to the basic communication with suppliers and customers is the only difference to existing research findings. It was also clear during the interviews that the entrepreneurs' focus was on client retention and not attraction, when it came to the use of ICT, which supports Molony's (2009) findings. What is also interesting is the fact that MEs use mobile phone primarily to communicate with customers and suppliers, which supports Steyn's (2011) findings.

\section{Level of Computer Literacy}

The lack of computer literacy is one of the biggest barriers to mobile ICT adoption (Chibelushi, 2008; Fathian, Akhavan, \& Hoorali, 2008; Good \& Qureshi, 2009; Kotelnikov, 2007; Matthews, 2007; Mutula \& Brakel, 2007; Wolcott et al., 2008). One assumes that a computer-literate person will be more aware of the benefits of ICT and thus be more likely to adopt it (Beggs, 2010).

Two of the female entrepreneurs have no experience with computers and one of the males says he knows a little about computers, but that he would not describe himself as literate. Two of the entrepreneurs have attended computer courses and two are being, or have been, taught by a friend or spouse. Three of the entrepreneurs (all male) are literate because it was or is a requirement for their previous or current job. Interestingly, the majority of the entrepreneurs who feel that they are computer literate are low adopters, contrasting with existing research findings. The main problem may be that this question is based on the entrepreneur's belief of whether they are computer literate or not and that their literacy level has not been objectively tested. When one studies the reasons why they believe they are literate, one sees that they have different opinions on what computer literacy means. One of the low adopters who believes he is computer literate only recently started attending a computer course and another was taught the basics of Word and e-mail use by her husband. One medium adopter says he can help himself "around a computer", but he believes this hardly means he is computer literate. Another of the computer literate, low adopters does not trust ICT at all, which overrides the knowledge of the advantages he has as a computer literate person. If one considers this, the results are more in line with the "computer literacy equals higher adoption" trend in current research.

\section{Keeping Up to Date with the Latest Technology Trends}

As mentioned before Beggs (2010) has found that one of the main barriers to mobile ICT adoption is the unawareness of the benefits of ICT. Four of the respondents say they do not try to keep up with the latest technology trends. One comment made was, "I am not interested in it and I don't think it is necessary". The majority of the respondents do keep up with the latest trends and here are some of their responses: 
"I learn from my children"

"I listen to what friends and family say about it"

"I follow the news"

"I do research on new technology trends"

Only one of the entrepreneurs who say that he keeps up to date with technology makes an effort to ensure that he has the latest information about technological developments; it is interesting to note that he is also a high mobile ICT adopter. This seems to indicate that staying abreast of what is happening in the world of technology may increase ICT adoption.

\section{Were You Exposed to Mobile ICT while Growing Up? Why or Why Not?}

This question aims to determine whether an entrepreneur's mobile ICT adoption level is influenced by their surroundings while growing up and what level of exposure they have had to ICT at a young age. Six of the entrepreneurs have had no exposure to ICT while growing up, one has been the first user of a mobile phone in his family and only one has had extensive exposure to technology while growing up at school and university.

It seems that there is some correlation between the person's early exposure to mobile ICT and their level of adoption. Those that have had exposure to the use of mobile technology in a business context at a younger age are all medium and high adopters.

\section{Do You Know of Other Entrepreneurs Who Use Mobile ICT as Part of Their Businesses?}

This question aims to determine if an entrepreneur's exposure to the use of mobile ICT by other entrepreneurs affects their own adoption level.

Four of the entrepreneurs know someone who uses mobile ICT in their businesses. Of the four, two are high adopters, one a medium and one a low adopter. The majority of the low adopters as well as two of the medium adopters do not know anyone who uses mobile ICT in their businesses.

This clearly implies that entrepreneurs who have exposure to or knowledge about how others use mobile ICT in their businesses are more likely to adopt mobile ICT themselves.

\section{Feelings and Thoughts on the Use of Mobile ICT for Business Purposes}

Generally, there seems to be a very positive attitude towards mobile ICT and many entrepreneurs mention the benefits it holds (Table 7). These results seem to indicate that providing training and access to mobile ICT would increase the chances of adoption. 
Table 7: Opinions on mobile ICT

\begin{tabular}{|c|c|}
\hline Opinion & Reasons \\
\hline \multicolumn{2}{|l|}{ Male } \\
\hline $\begin{array}{l}\text { Low adopter: "It empowers me and helps me } \\
\text { to communicate more effectively." }\end{array}$ & $\begin{array}{l}\text { "I know this from watching how others use it and } \\
\text { from my own experiences with it." }\end{array}$ \\
\hline $\begin{array}{l}\text { Low adopter: "It is a good thing, but it makes } \\
\text { people lazy." }\end{array}$ & $\begin{array}{l}\text { "Personal experience in my previous position. } \\
\text { Computers make people lazy and they trust every- } \\
\text { thing the computer tells them, without checking } \\
\text { that it is correct." }\end{array}$ \\
\hline $\begin{array}{l}\text { Medium adopter: "I would not be able to sur- } \\
\text { vive without it." }\end{array}$ & $\begin{array}{l}\text { "I have seen that it makes you immediately availa- } \\
\text { ble to people." }\end{array}$ \\
\hline $\begin{array}{l}\text { Medium adopter: "I think it is a good thing; } \\
\text { you would not be able to survive without it." }\end{array}$ & $\begin{array}{l}\text { "Technology has improved immensely and I be- } \\
\text { lieve you can achieve a lot with it." }\end{array}$ \\
\hline High adopter: "It is a very good thing." & $\begin{array}{l}\text { "I know this from my experience in the IT indus- } \\
\text { try." }\end{array}$ \\
\hline \multicolumn{2}{|l|}{ Female } \\
\hline Low adopter: "I think it is important" & $\begin{array}{l}\text { "Without it I will not be able to conduct business } \\
\text { when it is raining." }\end{array}$ \\
\hline $\begin{array}{l}\text { Low adopter: "It helps me to make my busi- } \\
\text { ness much better." }\end{array}$ & $\begin{array}{l}\text { "I have seen that it makes life easier for my cus- } \\
\text { tomer who can call me instead of driving to my } \\
\text { stall." }\end{array}$ \\
\hline $\begin{array}{l}\text { Low adopter: "It is very helpful, because it } \\
\text { reduces time and effort in my business." }\end{array}$ & "I have seen that it makes things easier." \\
\hline $\begin{array}{l}\text { Medium adopter: "If I had more skills I would } \\
\text { use it, because it helps make your business } \\
\text { better." }\end{array}$ & $\begin{array}{l}\text { "I think it is good, but if I had training I would } \\
\text { know for sure seeing as I would use it more." }\end{array}$ \\
\hline $\begin{array}{l}\text { High adopter: "I think mobile technology is } \\
\text { nice." }\end{array}$ & Based on personal experience using mobile ICT \\
\hline
\end{tabular}

\section{Have You Seen Any Advantages of Using Mobile Technology in Your Business? If So, Can You Explain in More Detail?}

As shown in Table 8, there are various benefits associated with the use of mobile ICT in a business (Chibelushi, 2008; Kotelnikov, 2007; Morgan et al., 2006; Molony, 2009). 
Table 8: Benefits of mobile ICT

\begin{tabular}{|c|c|}
\hline Adoption level & Perceived benefits \\
\hline High adopters & $\begin{array}{l}\text { - Enables quick and easy communication } \\
\text { - It is convenient and reliable } \\
\text { - It makes you accessible anytime and anywhere and improves commu- } \\
\text { nication }\end{array}$ \\
\hline Medium adopters & $\begin{array}{l}\text { - } \quad \text { It provided me with an advantage over my competitors initially when I } \\
\text { - } \quad \text { Impro one of the first to use it in my business." } \\
\text { - It makes you accessible } 24 \text { hours of the day } \\
\text { - It makes things easier } \\
\text { - "My communication and finances are managed easier and more effi- } \\
\text { ciently." }\end{array}$ \\
\hline Low adopters & 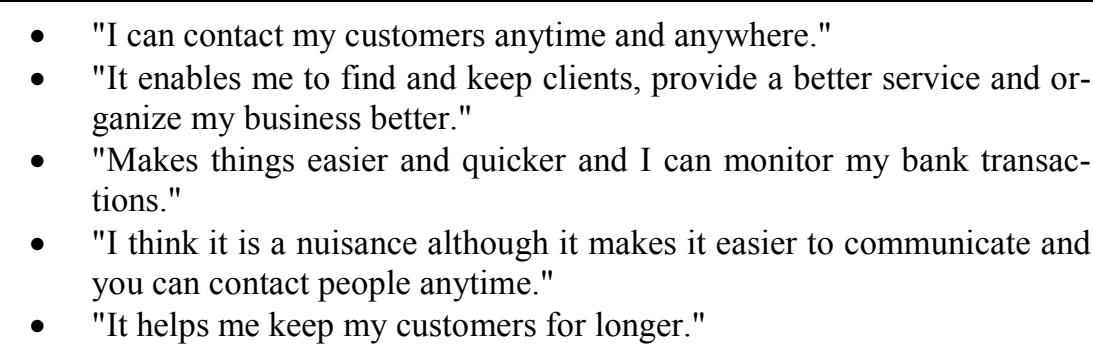 \\
\hline
\end{tabular}

It was interesting to note that one of the low adopters mentioned cell phone banking as an advantage, but they do not make use of it themselves. In general, the low adopters named more benefits than the high adopters did. This could indicate that the low adopters are aware of the benefits and want to use mobile ICT, but that adoption barriers prevent them.

\section{What Prevents You from Making Use of Mobile ICT?}

Table 9 lists the barriers identified by the interviewed entrepreneurs as well as the references to current research, which identify the same barrier.

Table 9. Barriers identified by entrepreneurs

\begin{tabular}{|c|c|c|c|}
\hline Barrier & $\begin{array}{l}\text { No of } \\
\text { entrepreneurs }\end{array}$ & $\begin{array}{l}\text { Similar barrier in } \\
\text { literature }\end{array}$ & Reference \\
\hline \multirow{2}{*}{ It is too expensive } & \multirow{2}{*}{$\begin{array}{l}4 \\
\text { (All low adopters) }\end{array}$} & $\begin{array}{l}\text { Expensive and complex } \\
\text { products }\end{array}$ & $\begin{array}{l}\text { (Beckinsale, Ram, \& } \\
\text { Theodorakopoulos, 2010; Esselaar et } \\
\text { al., 2008; Harindranath et al., 2008; } \\
\text { Kotelnikov, 2007; Morgan et al., } \\
\text { 2006; Wolcott et al., 2008) }\end{array}$ \\
\hline & & $\begin{array}{l}\text { Lack of finances and } \\
\text { resources }\end{array}$ & $\begin{array}{l}\text { (Chandy \& Narasimhan, 2011; } \\
\text { Chibelushi, 2008; Cecchini \& Scott, } \\
\text { 2003; Donner \& Escobari ,2010; } \\
\text { Good \& Qureshi, 2009; Kotelnikov, } \\
\text { 2007; Matthews, 2007; Scott et al, } \\
\text { 2004; Wolcott et al,. 2008) }\end{array}$ \\
\hline
\end{tabular}




\begin{tabular}{|c|c|c|c|}
\hline Barrier & $\begin{array}{l}\text { No of } \\
\text { entrepreneurs }\end{array}$ & $\begin{array}{l}\text { Similar barrier in } \\
\text { literature }\end{array}$ & Reference \\
\hline \multirow{2}{*}{$\begin{array}{l}\text { I have no skills or } \\
\text { knowledge about } \\
\text { ICT; I have never } \\
\text { tried it before }\end{array}$} & \multirow{2}{*}{$\begin{array}{l}4 \\
\text { (Three low and } \\
\text { one medium } \\
\text { adopter) }\end{array}$} & $\begin{array}{l}\text { Unawareness of ICT } \\
\text { benefits }\end{array}$ & $\begin{array}{l}\text { (Beggs, 2010; Chibelushi, 2008; Good } \\
\text { \& Qureshi, 2009; Harindranath et al., } \\
\text { 2008; Mutula \& Brakel, 2007; } \\
\text { Wolcott et al., 2008) }\end{array}$ \\
\hline & & $\begin{array}{l}\text { Lack of ICT } \\
\text { capabilities and literacy }\end{array}$ & $\begin{array}{l}\text { (Chibelushi, 2008; Fathian, Akhavan, } \\
\text { \& Hoorali 2008; Good \& Qureshi, } \\
\text { 2009; Kotelnikov, 2007; Matthews, } \\
\text { 2007; Mutula \& Brakel, 2007; } \\
\text { Wolcott et al., 2008) }\end{array}$ \\
\hline $\begin{array}{l}\text { I do not have access } \\
\text { to mobile ICT and } \\
\text { infrastructure }\end{array}$ & $\begin{array}{l}1 \\
\text { (Low adopter) }\end{array}$ & $\begin{array}{l}\text { Poor communication } \\
\text { infrastructure }\end{array}$ & $\begin{array}{l}\text { (Duncombe, 2006; Kotelnikov, 2007; } \\
\text { Matthews, 2007; Scott et al., 2004; } \\
\text { Tenhunen, 2008; Wolcott et al., 2008) }\end{array}$ \\
\hline $\begin{array}{l}\text { I have no transport } \\
\text { to get to ICT } \\
\text { training }\end{array}$ & $\begin{array}{l}1 \\
\text { (Low adopter) }\end{array}$ & $\begin{array}{l}\text { Lack of ICT } \\
\text { capabilities and literacy }\end{array}$ & $\begin{array}{l}\text { (Chibelushi, 2008; Fathian, Akhavan, } \\
\text { \& Hoorali 2008; Good, \& Qureshi } \\
\text { 2009; Kotelnikov, 2007; Matthews, } \\
\text { 2007; Mutula \& Brakel, 2007; } \\
\text { Wolcott et al., 2008) }\end{array}$ \\
\hline $\begin{array}{l}\text { I do not believe that } \\
\text { it is necessary for } \\
\text { my business; I do } \\
\text { not see the use of it. }\end{array}$ & $\begin{array}{l}3 \text { (One low } \\
\text { adopter and two } \\
\text { medium adopters) }\end{array}$ & $\begin{array}{l}\text { Unawareness of ICT } \\
\text { benefits }\end{array}$ & $\begin{array}{l}\text { (Beggs, 2010; Chibelushi, 2008; Good } \\
\text { \& Qureshi, 2009; Harindranath et al., } \\
\text { 2008; Mutula \& Brakel, 2007; } \\
\text { Wolcott et al., 2008) }\end{array}$ \\
\hline $\begin{array}{l}\text { I just don't like or } \\
\text { trust it. There are } \\
\text { too many issues } \\
\text { and faults } \\
\text { associated with it. }\end{array}$ & $\begin{array}{l}1 \\
\text { (Low adopter) }\end{array}$ & $\begin{array}{l}\text { Mistrust and negative } \\
\text { attitude towards } \\
\text { technology }\end{array}$ & $\begin{array}{l}\text { (Vickery et al., 2004; Wolcott et al., } \\
\text { 2008) }\end{array}$ \\
\hline $\begin{array}{l}\text { The area from } \\
\text { which I conduct } \\
\text { business prevents } \\
\text { me from using } \\
\text { more mobile ICT, } \\
\text { there is no } \\
\text { electricity and it is } \\
\text { not safe. }\end{array}$ & $\begin{array}{l}2 \\
\text { (Both are high } \\
\text { adopters) }\end{array}$ & $\begin{array}{l}\text { Unreliable power } \\
\text { supply }\end{array}$ & (Matthews, 2007) \\
\hline
\end{tabular}

Similar to most of the current literature the cost of mobile ICT was one of the top barriers amongst the interviewed entrepreneurs. Noticeably only low adopters mentioned cost as a barrier. It is also interesting that two of the entrepreneurs feel that mobile ICT is not too expensive and that you can find mobile ICT, which will suit your pocket.

One entrepreneur believes that he does not need mobile ICT seeing as his business is small, he feels he would use mobile ICT more if his business was bigger. Another has stated that she is not sure why she does not use more mobile ICT as she has the intention to, but never follows through on her plans. The two high adopters have both only named one barrier, the fact that their location is not secure and does not have electricity access. 


\section{What Would Motivate You to Use More Mobile ICT?}

Tan et al. (2006) found that even when certain barriers to ICT adoption are removed, entrepreneurs may still not adopt ICT. This indicates that removing barriers on their own is not enough to promote adoption; one must motivate entrepreneurs to utilize mobile ICT (Table 10).

Table 10: Motivators of mobile ICT adoption

\begin{tabular}{|l|l|}
\hline Motivator & No of entrepreneurs \\
\hline Training & 5 \\
\hline Someone to ask for advice & 1 \\
\hline "If it was less expensive and I could afford it." & 3 \\
\hline "If I had access to a safe environment with electricity access." & 1 \\
\hline $\begin{array}{l}\text { "I don't think my business can benefit from mobile ICT so nothing will } \\
\text { motivate me to use it." }\end{array}$ & 1 \\
\hline $\begin{array}{l}\text { "If my business was bigger, that would motivate me to use it. I need ICT } \\
\text { to manage a big business not to get it to grow." }\end{array}$ & 1 \\
\hline "I can't think of anything." & 1 \\
\hline
\end{tabular}

Lower prices and training came up most often as sources of motivation to adopt mobile ICT.

\section{If You Could Obtain Cheap and Easy Access to Mobile ICT, Would You Make Use of It For Business Purposes? Why or Why Not?}

Tan et al. (2006) have found that many entrepreneurs feel they would not necessarily increase their ICT adoption when it is made more accessible and less expensive. Two of the respondents had no interest in using it, the rest said yes. Some of the comments are: "The cost currently prevents me from using it"; "It would enable me to get more for less to improve my business."; "It would enable me to make my business more functional."

These findings support those of Tan et al. (2006) to some extent, seeing as two of the entrepreneurs have no interest in increasing their mobile ICT adoption even if it is provided at a lower rate and made more accessible. One of them is of the opinion that he does not need any other mobile technology than what he is currently using; he would just upgrade the existing technology. The other one is very mistrustful of technology.

Quite a few people state cost as a barrier to adoption, but add that they would use more mobile ICT if it were cheaper. This might be an indication that entrepreneurs are unaware of what exactly prevents them from using mobile ICT.

\section{Do You Trust ICT? If Not Why Not?}

Wolcott et al. (2008) and Vickery et al. (2004) state that many entrepreneurs mistrust or have a negative attitude towards mobile ICT.

Only three entrepreneurs state that they trust mobile ICT. The rest all reply that they only trust it to some extent. Some of the reasons why they mistrust ICT are that people make mistakes while using mobile ICT, others misuse mobile ICT for crimes like identity theft and one entrepreneur does not trust doing mobile banking because of the high fraud rates. 


\section{Who Helps You Decide What Technology to Use?}

Table 11 shows who respondents ask for advice.

Table 11: Sources of advice for mobile ICT adoption

\begin{tabular}{|l|l|}
\hline Source of advice & No of entrepreneurs \\
\hline "I ask friends." & 2 \\
\hline "I consult with people I know are knowledgeable about ICT." & 2 \\
\hline "I ask my husband for advice.” & 2 \\
\hline "I ask my uncle or other family members for advice.” & 1 \\
\hline "I do research and decide on my own." & 3 \\
\hline "I consult with my business partners." & 1 \\
\hline "I have no one I can ask for advice." & 1 \\
\hline
\end{tabular}

Something that points to the gender norms barrier identified by Chew et al. (2010) is that one of the female entrepreneurs has had a chance to obtain a laptop, but her husband declined it, because she did not need it according to him. She accepts this decision, despite the fact that she feels she could benefit from a laptop.

\section{Research Findings}

The research questions will now be answered based on the findings obtained through analysis of the interview data.

\section{What is Currently Preventing South African ME Entrepreneurs from Using Mobile ICT in Their Businesses?}

During the interviews various barriers have been identified by the entrepreneurs themselves and others and have become apparent during the data analysis. Based on the data, Table 12 lists barriers currently preventing South African ME entrepreneurs from using mobile ICT in their businesses. The references to existing research, which identifies similar barriers, are listed next to the relevant barrier.

Table 12: Barriers preventing mobile ICT adoption amongst South African entrepreneurs

\begin{tabular}{|l|l|l|}
\hline Barrier & Research findings & Related research \\
\hline & $\begin{array}{l}\text { Entrepreneurs who keep themselves in- } \\
\text { formed about the latest trends and benefits } \\
\text { of technology tend to be high adopters of } \\
\text { mobile ICT. }\end{array}$ & $\begin{array}{l}\text { (Beggs, 2010; Chibelushi, } \\
\text { 2008; Good \& Qureshi, } \\
\text { ICT benefits }\end{array}$ \\
& $\begin{array}{l}\text { Many entrepreneurs do not see the benefit } \\
\text { that mobile ICT holds or they believe that } \\
\text { their businesses do not need mobile ICT. }\end{array}$ & $\begin{array}{l}\text { 2008; Mutula \& Brakel, } \\
\text { 2007; Wolcott et al. 2008) }\end{array}$ \\
\hline $\begin{array}{l}\text { Business skills } \\
\text { shortage }\end{array}$ & $\begin{array}{l}\text { The research shows a correlation between } \\
\text { the rate of mobile ICT adoption and a high } \\
\text { level of business training. }\end{array}$ & $\begin{array}{l}\text { (Chandy \& Narasimhan, } \\
\text { 2011; Wolcott et al., 2008) }\end{array}$ \\
\hline
\end{tabular}




\begin{tabular}{|c|c|c|}
\hline Barrier & Research findings & Related research \\
\hline $\begin{array}{l}\text { Lack of ICT capa- } \\
\text { bilities and literacy }\end{array}$ & $\begin{array}{l}\text { Computer illiterate entrepreneurs have a } \\
\text { lower mobile ICT adoption rate than lit- } \\
\text { erate entrepreneurs do. If you do not know } \\
\text { how to use mobile ICT, you are less likely } \\
\text { to know about its benefits and why you } \\
\text { should adopt it. } \\
\text { Many micro entrepreneurs believe them- } \\
\text { selves to be computer literate, while they } \\
\text { are not. This is a problem, as they see no } \\
\text { need to attend computer training, reducing } \\
\text { their chances of adopting more mobile } \\
\text { ICT. } \\
\text { Many entrepreneurs also state that lack of } \\
\text { training on how to incorporate mobile ICT } \\
\text { in their businesses, prevents them from } \\
\text { using it more. }\end{array}$ & $\begin{array}{l}\text { (Chibelushi, 2008; Fathian, } \\
\text { Akhavan, \& Hoorali, 2008; } \\
\text { Good \& Qureshi, 2009; } \\
\text { Kotelnikov, 2007; } \\
\text { Matthews, 2007; Mutula \& } \\
\text { Brakel, 2007; Wolcott et } \\
\text { al., 2008) }\end{array}$ \\
\hline $\begin{array}{l}\text { Expensive and } \\
\text { complex products }\end{array}$ & $\begin{array}{l}\text { Many MEs see this as a main barrier to } \\
\text { adoption. }\end{array}$ & $\begin{array}{l}\text { (Beckinsale, Ram, \& } \\
\text { Theodorakopoulos 2010; } \\
\text { Esselaar et al., 2008; ; } \\
\text { Harindranath et al., 2008; } \\
\text { Kotelnikov, 2007; Morgan } \\
\text { et al., 2006; Wolcott et al., } \\
\text { 2008) }\end{array}$ \\
\hline $\begin{array}{l}\text { Poor communica- } \\
\text { tion infrastructure }\end{array}$ & $\begin{array}{l}\text { Entrepreneurs in the remote areas struggle } \\
\text { to gain access to reliable communication } \\
\text { services. }\end{array}$ & $\begin{array}{l}\text { (Duncombe, 2006; } \\
\text { Kotelnikov, 2007; } \\
\text { Matthews, 2007; Scott, et } \\
\text { al. 2004; Tenhunen ,2008; } \\
\text { Wolcott et al., 2008) }\end{array}$ \\
\hline $\begin{array}{l}\text { Lack of finances } \\
\text { and resources }\end{array}$ & $\begin{array}{l}\text { Many MEs see this as a main barrier to } \\
\text { adoption. }\end{array}$ & $\begin{array}{l}\text { (Cecchini \& Scott, 2003; } \\
\text { Chandy \& Narasimhan, } \\
\text { 2011; Chibelushi, 2008; } \\
\text { Donner \& Escobari, 2010; } \\
\text { Good \& Qureshi, 2009; } \\
\text { Kotelnikov, 2007; } \\
\text { Matthews, 2007; Scott et } \\
\text { al., 2004; Wolcott et al., } \\
\text { 2008) }\end{array}$ \\
\hline Level of education & $\begin{array}{l}\text { The more educated micro entrepreneurs } \\
\text { are, the more likely they are to be high } \\
\text { mobile ICT adopters, possibly because } \\
\text { computer training is currently included in } \\
\text { most forms of education. }\end{array}$ & $\begin{array}{l}\text { (Chew et al., 2010; } \\
\text { Chibelushi, 2008; }\end{array}$ \\
\hline $\begin{array}{l}\text { Unreliable power } \\
\text { supply }\end{array}$ & $\begin{array}{l}\text { Many micro entrepreneurs state that they } \\
\text { would use more mobile ICT if they had } \\
\text { access to a power source at their business } \\
\text { location. }\end{array}$ & (Matthews, 2007) \\
\hline
\end{tabular}




\begin{tabular}{|l|l|l|}
\hline Barrier & Research findings & Related research \\
\hline No external advice & $\begin{array}{l}\text { Micro entrepreneurs, who do not have } \\
\text { someone to consult about business tech- } \\
\text { nology, tend to have a low adoption rate. }\end{array}$ & $\begin{array}{l}\text { (Morgan et al., 2006; } \\
\text { Wolcott et al., 2008) }\end{array}$ \\
\hline $\begin{array}{l}\text { Social and gender } \\
\text { norms }\end{array}$ & $\begin{array}{l}\text { Men tend to be slightly higher adopters of } \\
\text { mobile ICT than women are and some of } \\
\text { the women who were interviewed allow } \\
\text { their husbands to make choices for them } \\
\text { concerning the use of mobile ICT in their } \\
\text { business. In one case, a woman's husband } \\
\text { turned down mobile ICT that she feels she } \\
\text { really needs for her business and she has } \\
\text { accepted his decision. }\end{array}$ & (Chew et al., 2010) \\
\hline $\begin{array}{l}\text { Mistrust and nega- } \\
\text { tive attitude to- } \\
\text { wards technology }\end{array}$ & $\begin{array}{l}\text { Many people still do not trust technology } \\
\text { for reasons like the fact that you cannot } \\
\text { trust people to use mobile ICT honestly } \\
\text { and without making any mistakes. }\end{array}$ & (Vickery et al., 2004; \\
\hline $\begin{array}{l}\text { Type of organiza- } \\
\text { tion }\end{array}$ & $\begin{array}{l}\text { Businesses that sell goods tend to be high- } \\
\text { er adopters of mobile ICT than service } \\
\text { based businesses. }\end{array}$ & $\begin{array}{l}\text { No current research was } \\
\text { found. }\end{array}$ \\
\hline $\begin{array}{l}\text { Location of busi- } \\
\text { ness is not safe or } \\
\text { secure. }\end{array}$ & $\begin{array}{l}\text { Entrepreneurs state that they would adopt } \\
\text { more mobile ICT if they had a safe envi- } \\
\text { ronment from which to conduct their } \\
\text { businesses. }\end{array}$ & $\begin{array}{l}\text { No current research was } \\
\text { found. }\end{array}$ \\
\hline
\end{tabular}

From Table 12 one can see that many of the barriers identified in current literature are applicable to South African entrepreneurs, although many others have not appeared in the course of the research done for this paper.

Two new barriers are identified during the course of this research paper:

- It appears that the type of business in itself can be a barrier to mobile ICT adoption. Micro entrepreneurs with service-based businesses had a much higher adoption rate than those entrepreneurs with businesses that sell goods.

- Some entrepreneurs have indicated that they do not feel the area they conduct their business in is safe and secure enough. They do not use multiple forms of mobile ICT as they cannot carry all of these to their business location, they have no place to store it overnight and they do not want to risk having their mobile ICTs stolen.

It is also important to note that most micro entrepreneurs' mobile ICT adoption level is determined by a combination of barriers. It would therefore be difficult to create one fool proof solution to improve the adoption level of all micro entrepreneurs in South Africa.

- Why or for what purposes are ME entrepreneurs currently using mobile technology?

Currently mobile phones are the most popular form of mobile ICT for micro entrepreneurs (Herrington et al., 2009), although only a small section of the mobile phone's full capabilities are being used. Only a small number of entrepreneurs utilises the internet access that their phones provide and very few make use of any other phone capability except texting and phone calls.

The main uses for mobile phones by South African entrepreneurs are as follows: 
- Communication with employees, clients and suppliers;

- Coordinating deliveries and orders;

- Mobile banking;

- Mobile advertising.

These entrepreneurs make use of mobile ICT as they see various benefits in the use of these devices. They also feel pressured by competitors, clients and friends to use mobile ICT to run their businesses.

\section{What are the Current Perceptions that These Entrepreneurs Have of Mobile Information Technology?}

In general, the majority of entrepreneurs have a very positive attitude towards and opinion of mobile ICT. They state that it empowers them, that they would not be able to survive without it and that it helps them make their businesses more effective. Both low and high adopters are able to list a number of benefits that they feel mobile ICT holds for a business.

It is interesting to note that although many entrepreneurs could list benefits of using mobile ICT there are those that do not use it, despite awareness of its worth. One such entrepreneur does not approve of the use of mobile ICT as, according to him, it "makes people lazy." The majority of South African entrepreneurs also state that they trust ICT but not the people who use ICT. Many list fraud, mistakes and identity theft as reasons why they cannot trust ICT outright.

Most of these perceptions are based on personal experience with the use of mobile ICT in a business context or training. One of the entrepreneurs has stated that they would probably have a higher opinion of mobile ICT if they receive training, as this would enable them to make an educated decision on the worth of mobile ICT in a business. The negative perceptions that many entrepreneurs have of mobile ICT is a major obstacle in increasing the adoption of mobile ICT.

\section{Research Limitations}

There are various limitations, which have influenced the outcome of this research paper. The fact that only ten entrepreneurs have been interviewed could mean that important barriers were overlooked. The entrepreneurs also come from the same area so that it is difficult to generalise the data to all South African entrepreneurs.

Additionally the researchers had to face challenges in finding a classification method for adoption of mobile ICT amongst micro entrepreneurs. There is no current literature on how to rate or scale the level of adoption of an entrepreneur. Research to develop a framework by which one can determine the extent or complexity of ICT, that a specific ME requires, may be valuable. An indepth study on the current uses of mobile technology by MEs and how to redirect these to become more business orientated could also prove to be worthy.

\section{Conclusion}

From the findings, one can see that there are various internal and external forces that determine the level of mobile ICT adoption by South African entrepreneurs. Many of these factors are not unique to South African entrepreneurs as one can see from the literature. Each entrepreneur has their own unique mix of factors, which influences their adoption.

These findings contribute to the knowledge on how South African micro entrepreneurs can be encouraged to adopt more mobile ICTs in order to grow their businesses and benefit the economy of the country. 


\section{References}

AlAwadhi, S., \& Morris, A. (2008). The use of the UTAUT model in the adoption of e-government services in Kuwait. In 41st Hawaii International Conference on System Sciences, 7-10 January 2008 Waikoloa, Big Island, HI, USA. 1 - 11.

Barba-Sánchez, V., Martínez-Ruiz, M. P., \& Jiménez-Zarco, A. I. (2007). Drivers, benefits and challenges of ICT adoption by small and medium sized enterprises ( SMEs): A literature review. Problems and Perspectives in Management, 5(1), 103-114.

Beckinsale, M., Ram, M., \& Theodorakopoulos, N. (2010). ICT adoption and ebusiness development: Understanding ICT adoption amongst ethnic minority businesses. International Small Business Journal, 29(3), 193-219.

Beggs, E. (2010). Is there a correlation between SME Owner/Managers' characteristics and ICT adoption in Business Communications? Dublin Business School.

Bourgouin, F. (2002). Information communication technologies and the potential for rural tourism SMME development : The case of the Wild Coast. Development Southern Africa, 19(1), 191-212.

Cecchini, S., \& Scott, C. (2003). Can information and communications technology applications contribute to poverty reduction? Lessons from rural India. Information Technology for Development, 10(2), 7384.

Chandy, R., \& Narasimhan, O. (2011). How micro entrepreneurs could change the world. Business Strategy Review, 52-55.

Chatzoglou, P. D. \& Vraimaki, E. (2010). Computer acceptance in Greek SMEs. Journal of Small Business and Enterprise Development, 17 (1), 78 - 101.

Chew, H. E., Ilavarasan, P. V., \& Levy, M. R. (2010). The economic impact of information and communication technologies on microenterprises in the context of development. Information Systems In Developing Countries, 44(4), 1-19.

Chibelushi, C. (2008). Learning the hard way? Issues in the adoption of new technology in small technology oriented firms. Education + Training, 50(8/9), 725-736.

Donner, J. (2004). Micro entrepreneurs and mobiles : An exploration of the uses of mobile phones by small business owners in Rwanda. Information Technologies and International Development, 2(1), 1-21.

Donner, J. (2007). The use of mobile phones by microentrepreneurs in Kigali, Rwanda: Changes to social and business networks. Information Technologies and International Development, 3(2), 3-19.

Donner, J., \& Escobari, M. X. (2010). A review of evidence on mobile use by micro and small enterprises in developing countries. Journal of International Development, 22, 641-658.

D.O.T.I. (1996). National small business act. South Africa.

Duncombe, R. (2006). Using the livelihoods framework to analyze ICT applications for poverty reduction through microenterprise. Information Technologies and International Development, 3(3), 81-100.

Esselaar, S., Stork, C., Ndiwalana, A., \& Deen-Swarray, M. (2008). ICT usage and its impact on profitability of SMEs in 13 African countries. Information Technologies and International Development, 4(1), 87-100.

Fathian, M., Akhavan, P., \& Hoorali, M. (2008). E-readiness assessment of non-profit ICT SMEs in a developing country: The case of Iran. Technovation, 28(9), 578-590.

Gatautis, R. \& Vitkauskaite, E. (2009). eBusiness policy support framework. Inzinerine EkonomikaEngineering Economics, 5, 35 - 47.

Good, T., \& Qureshi, S. (2009). Investigating the effects of micro-enterprise access and use of ICTs through a capability lens: Implications for global development. In Second Annual SIG GlobDev Workshop. Phoenix, USA, pp.1-28. 
Harindranath, G., Dyerson, R., \& Barnes, D. (2008). ICT adoption and use in UK SMEs : A failure of initiatives? Information Systems Evaluation, 11(2), 91-96.

Hermana, B., Sugiharto, T., \& Margianti, E. S. (n.d.). ICT adoption by Indonesian small business owners: Preliminary study. Gundarma University.

Herrington, M., Kew, J., \& Kew, P. (2009). Tracking entrepreneurship in South Africa: A GEM perspective. Rothko.

Ilavarasan, P. V. ,\& Levy, M. R. (2012). ICT access and use by micro entrepreneurs in Mumbai, India: A value chain model analysis. In Information Communication Technology Development, pp. 259-267.

Kabanda, S. (2001). "E-Commerce institutionalization is not for us": SMEs perception of E-Commerce in Tanzania. The African Journal of Information Systems, 3(1), 1-16.

Kahn, G. F., Moon, J., Rhee, C., \& Rho, J. J. (2012). E-government skills identification and development: toward a staged-based user-centric approach for developing countries. Asia Pacific Journal of Information Systems, 20(1), 1 - 31.

Kapurubandara, M., \& Lawson, R. (2007). SMEs in developing countries need support to address the challenges of adopting e-commerce technologies. In 20th Bled eConference eMergence and Emerging Technologies, Processes and Institutions, 4 - 6 June 2007 2007. 485 - 498.

Kenny, C. J. (2002). Expanding Internet access to the rural poor in Africa. Information Technology for Development, 9(1), 25-31.

Klein, H. K., \& Myers, M. D. (1999). A set of principles for conducting and evaluating interpretive field studies in information systems. MIS Quarterly, 23(1), 67-94.

Kotelnikov, V. (2007). Small and medium enterprises and ICT. Keen Media Thailand.

Ladzani, W. M. \& van Vuuren, J. J. (2002). Entrepreneurship training for emerging SMEs in South Africa. Journal of Small Business Management, 40 (2), 154 - 161.

MacGregor, R. C. (2004). Factors associated with formal networking in regional small business: Some findings from a study of Swedish SMEs. Journal of Small Business and Enterprise Development, $11(1), 60-74$.

Matthews, P. (2007). ICT Assimilation and SME Expansion. Journal of International Development, 19(6), $817-827$.

Miller, D., \& Garnsey, E. (2000). Entrepreneurs and technology diffusion How diffusion research can benefit from a greater understanding of entrepreneurship. Technology in Society, 22, (445 - 465.)

Molony, T. (2009). Carving a niche : ICT, social capital, and trust in the shift from personal to impersonal trading in Tanzania. Information Technology for Development, 15(4), 283-301.

Morgan, A., Colebourne, D., \& Thomas, B. (2006). The development of ICT advisors for SME businesses: An innovative approach. Technovation, 26(8), 980-987.

Mutula, S. M., \& van Brakel, P.V. (2007). ICT skills readiness for the emerging global digital economy among small businesses in developing countries: Case study of Botswana. Library Hi Tech, 25(2), $231-245$.

Myers, M. D. (2009). Qualitative research in business and management. London EC1Y 1SP: SAGE Publications Ltd.

Ndubisi, N. O., \& Kahraman, C. 2005. Malaysian women entrepreneurs: Understanding the ICT usage behaviors and drivers. Journal of Enterprise Information Management, 18(6), 721 - 738.

Nguyen, T. H. (2009). Information technology adoption in SMEs: An integrated framework. International Journal of Entrepreneurial Behaviour \& Research, 15(2), 162 - 186.

Oye, N. D., Ihhad, N. A., \& Ab.Rahim, N. (2012). The history of UTAUT model and its impact on ICT acceptance and usage by academicians. Educ Inf Technol. 
Ramani, S. V., SadreGhazi, S., \& Duysters, G. (2012). On the diffusion of toilets as bottom of the pyramid innovation: Lessons from sanitation entrepreneurs. Technological Forecasting \& Social Change, 79, $676-687$.

Reid, G. C., \& Smith, J. A. (2000). What makes a new business start-up successful? Small Business Economics, 14, 165-182.

Reimenschneider, C. K., Harrison, D. A., \& Mykytyn, P. P. (2003). Understanding it adoption in small business: integrating current theories. Information \& management, 40, 269-285.

Saunders, M., Lewis, P., \& Thornhill, A. (2003). Research methods for business students, Harlow, England: Pearson Education Limited.

Scott, N., Batchelor, S., Ridley, J., \& Jorgensen, B. (2004). The impact of mobile phones in Africa. Commission In Africa.

Spencer, A. J., Buhalis, D. \& Moital, M. 2012. A hierarchical model of technology adoption for small owner-managed travel firms: An organizational decision-making and leadership perspective. Tourism Management, 33, (1195 - 1208.

Steyn, A. A. (2011). E-Skills for entrepreneurs: A preliminary study. In ResNes Colloquium, October 2011 East London, SA.

Svanaes, D., Alsos, O. A., \& Dahl, Y. (2010). Usability testing of mobile ICT for clinical settings: Methodological and practical challenges. International Journal of Medical Informatics, 79(4), 24-34.

Tan, Y. L., Macaulay, L. A., \& Scheurer, M. (2006). Adoption of ICT among small business: Vision versus reality. In European and Mediterranean Conference on Information Systems. pp. 1-10.

Tenhunen, S. (2008). Mobile technology in the village: ICTs, culture, and social logistics in India. Journal of the Royal Anthropological Institute, 14(3), 515-534.

Thomas, B., Packham, G., Miller, C., \& Brooksbank, D. (2004). The use of web sites for SME innovation and technology support services in Wales. Journal of Small Business and Enterprise Development, $11(3), 400$ - 407.

Twinomurinzi, H., Phahlamohlaka, J., \& Byrne, E. (2012). The small group subtlety of using ICT for participatory governance: A South African experience. Government Information Quarterly, 29, 203 - 211.

Uddin, M. K. (2005). The role of diffusion of innovations for incremental development in small enterprises. Technovation, 26, 274 - 284.

Vickery, G., Sakai, K., Lee, I., \& Hagbong, S. (2004). ICT, e-business and SMEs. OECD Conference of Ministers Responsiblie for SMEs. Istanbul, Turkey: OECD Publications, pp. 2 - 48.

Wamuyu, P. K. \& Maharaj, M. 2011. Factors influencing successful use in mobile technologies to facilitate e-commerce in small enterprises: The case of Kenya. The African Journal of Information Systems, $3(2), 47-71$.

Wolcott, P., Kamal, M., \& Qureshi, S. (2008). Meeting the challenges of ICT adoption by microenterprises. Journal of Enterprise Information Management, 21(6), 616-632. 


\section{Biographies}

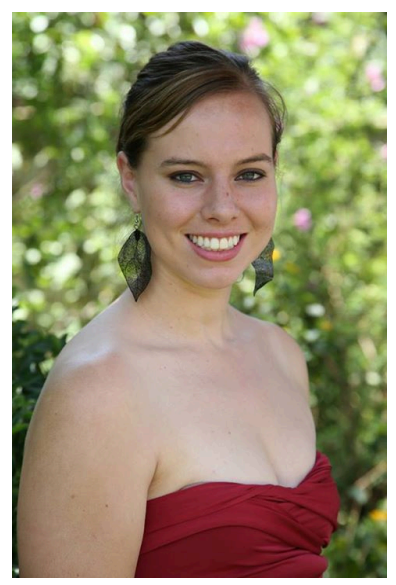

Eunice Steyn matriculated in 2008 at the high school Wonderboom (South Africa). After high school she completed her Bcom Informatics and Informatics Honours degrees, Cum Laude at the University of Pretoria. Eunice is currently working as a Business Consultant for $\mathrm{BSG}$, assisting them with the creation of world class solutions to business problems and contributing to their vision to be a proactive force for positive change. Eunice also serves as the Vice President of The Association of Allan Gray Fellows a start-up community aimed at providing entrepreneurial and leadership support to entrepreneurs. Eunice is interested in research regarding the impact that information technology has and can have on improving leadership, entrepreneurship and small business growth.

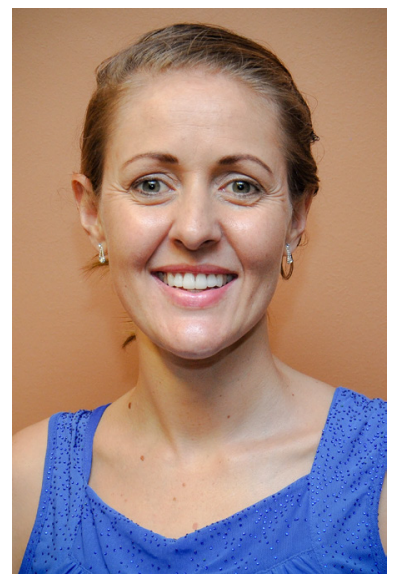

Riana Steyn matriculated in 2000 in South Africa. After school she studied at the University of Pretoria and obtained a BCOM (Hons) degree specialising in Informatics in 2004. She then worked in the industry as an IT manager as well as Information manager until 2008 when she joined the University of Pretoria as a full-time lecturer. In 2010 she obtained her Masters in Informatics Cum Laude. She is still a young academic with interest in the management of IT especially within small companies and entrepreneurs and how IT can be used to enhance entrepreneurs' businesses. Her PhD studies focus on incorporate ICT training within an existing entrepreneurship training model to assist the South African to adopt ICT effectively.

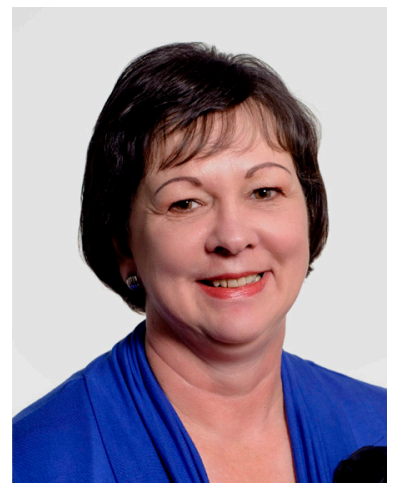

Professor Carina de Villiers is currently full professor and was Head of the Department of Informatics from 2000 until 2011 at the University of Pretoria (UP), South Africa. She obtained a BSc(Computer Science and Mathematics), Higher Education Diploma, Diploma in Tertiary Education, MEd (Didactics) cum laude, Honours degree in Computer Science and a $\mathrm{PhD}$ (Informatics) degree. She started her career in 1979 as a junior lecturer at the University of South Africa and joined the University of Pretoria as an associate professor in 1996. She also served as Chairperson of the School of Information Technology, consisting of three departments, from 2002 to 2005. She has co-authored 9 books, 26 articles in peer-reviewed international journals and delivered more than 90 international and national conference papers on different topics in Information Systems and IS Education. She is a member of several international bodies and serves on a number of editorial and advisory boards for journals, including IT for Development and AIS Transactions for HCI. She holds a National Research Foundation rating as an established IS researcher since 2000. The Department of Informatics received ABET accreditation under her leadership in 2008. 